\title{
The Realities of Teacher Distribution in Primary and Junior High Schools in Ghana: Experiences of Rural Areas in Sekyere Central District
}

\author{
Moses Azerimi Azewara ${ }^{1^{*}(\mathbb{C})}$, Okyere Korankye ${ }^{1}$, Emmanuel Amankwah $^{1}$, Matthew Takyi ${ }^{2}$ \\ ${ }^{1}$ St. Monica's College of Education, P.O.Box 250 Mampong-Ashanti, Ghana \\ ${ }^{2}$ Department of Social Sciences, Berekum College of Education, Berekum \\ Email: azewaramoses@gmail.com
}

Received: 15 May 2021; Revised: 6 July 2021; Accepted: 6 July 2021

\begin{abstract}
The study critically looked at teacher distribution in Ghana's Primary and Junior High Schools in Sekyere Central District; in the Ashanti Region of Ghana. Data were gathered from Education Monitoring Information Systems (EMIS) from the District Education Office, Nsuta for the analysis. Evidence from the rural communities in teacher deployment for the 2021 academic year for 10 rural Primary Schools and 5 Junior High Schools depicted a gloomy picture because there was uneven teacher deployment to these areas where their services are needed. There was a huge teacher deficit in the rural communities so the question of quality and equitable education will not be achieved if policymakers fail to provide incentive packages to the rural teachers. The paper recommends that rural teachers' conditions of service should be different from those of their colleagues in the urban areas. When this is done, teacher manpower utilization and retention of teachers in rural communities would be improved.
\end{abstract}

Keywords: realities, teacher distribution, primary schools, junior high schools, rural areas, Ghana

\section{Introduction}

Global debates on teacher management literature on how to balance and ensure fair deployment of human resources to all schools especially in the developing world are still problematic. In developing countries, there is an inadequate supply of teachers in rural areas whereas schools in urban centers are overstaffed with qualified teachers which is not a new conversation. Across all developing countries, an estimated 63 percent of public expenditure on education is spent on teachers' salaries (Crawfurd \& Pugatch, 2020). A majority of the countries in the Africa Region are struggling to break even with teacher demand and supply to bring about positive and desirable changes in learners' behaviour. Weak national systems of teacher supply and accountability result in huge disparities in teacher postings and transfers in the region. In this vein, inadequate data on the total number of teachers and vacant schools to post these teachers to the regions is problematic (World Bank Group, 2016). There have been many discussions of how the developing world will meet the high demand of qualified teachers while simultaneously focusing on improving educational quality. Schools are growing rapidly while at the same time the systems to recruit, train and retain an adequate number of qualified teachers struggle to keep pace (Bird et al., 2013). After a decade of consistent focus on universal access to education and

Copyright (C2021 Moses Azerimi Azewara, et al.

DOI: https://doi.org/10.37256/ser.222021939

This is an open-access article distributed under a CC BY license

(Creative Commons Attribution 4.0 International License)

https://creativecommons.org/licenses/by/4.0/ 
great strides in that effort under the UNESCO, Education for All (EFA) plan, the work of the international educational development community has widened its focus to include not just access to education but enhancing the capacity of education that is available. The previous goals under EFA did not include consideration of teachers; while the new longterm educational goals established in 2015 include teachers, it is still in a manner that limits the teacher role to a means of implementation and a set of qualifications (UNESCO, 2016).

Some studies have indicated that quality teachers who can provide hands-on learning opportunities for students are instrumental in improving learning outcomes for students (UIS, 2016; Witoszek, 2018). This increased understanding of the benefits of educational inputs has contributed to the fruition of Strategic Development Goal 4.c in the most recent UN development plan which calls for the international development community to support teacher training and support in third-world countries. According to the United Nations Sustainable Development Goal (SDG) 4, "ensure education is made accessible to all manner of persons" 4c by 2030 substantially expand teacher population, global interconnectivity as well as developing Islands states" (UN Education 2030, 2015). The Incheon Declaration and Framework for Action (UNESCO et al., 2015) which informed the establishment of the SDG Goal 4 emphasise that: teachers are the key to achieving all of the Education 2030 agenda ... As teachers are a fundamental pillar, they must be well resourced for them to be able to work assiduously to achieve educational outcomes (UNESCO et al., 2015). Again, the Institute of Statistics (UIS) 2016 study of global teacher demand is approximately seventeen million that is required to balance the number of school children in Sub-Saharan Africa by 2030. In the context of both the developed and least developed countries, teacher supply is a major issue. According to the South African Council of Educators (2010), "even after choosing teaching as a profession, the individual has to choose a geographic location to work in ... that decision is affected by both the financial and non-financial rewards of being in teaching in that particular location". Addressing the issues of recruitment, deployment and retention of teachers requires accurate and timely information. The World Bank (2010) notes: "teacher deployment presents a very significant challenge when management and information systems are rarely providing information for authorities to assess how teachers are deployed let alone approach the questions of equitable distribution".

It is important to distinguish between a teacher shortage and an inefficient distribution of teachers leading to a situation in which teachers are lacking in the most remote schools where they are needed most (World Bank Group, 2016). Teachers who are part of the communities in which they teach may be more likely to have personal values that resonate with the larger values of the community in which they work, as compared to teachers who are deployed to unfamiliar areas (Buckler, 2015). According to Dladla and Moon (2013), the difficulties teachers encounter in the remote communities in Sub-Saharan Africa (include large class sizes, poor facilities, low pay, and limited access to amenities), do not facilitate teaching and learning in these remote places. Teachers in third-world countries, prefer to work in developed communities with all social amenities such as electricity and water (Asim et al., 2017; Acheampong \& Gyasi, 2019; Anlimachie, 2015; 2016; Ansong et al., 2018). There is a mismatch between the number of teachers to be trained and the quantum of resources needed to train these human resources due to inaccurate data (Nilsson, 2003; Lumor, 2016). This is important because the focus should be on the quality of human resources rather than quantity. Oftentimes, unqualified teachers are hired due to budgetary deficits in the developing world (UNESCO, 2015).

\section{The Ghanaian experience}

The deployment of teachers in Ghana over the years saw a quantum leap but timid approach by policymakers making it difficult to evenly distribute teachers to areas where their services are needed. In Ghana, the majority of teachers do not like to work in rural communities. Successive governments have implemented state-driven policies to sponsor teachers with the intention that they will contribute their quota to the development of education in Ghana after completion of their studies, yet some of these teachers normally refuse postings to rural areas in the country.

In May 2006, a study was conducted in five districts in the Central Region of Ghana, and the findings portrayed a bleak picture about teacher distribution in Primary and Junior High schools in these districts. Out of 4,488 teachers in these districts, $2,711(60.4 \%)$ were trained whereas 1,777 (39.6\%) were untrained. Furthermore, the teacher: pupil ratio was 1:59 (one teacher per 59 pupils in class).

Another survey on teacher attrition conducted by Ghana National Association of Teachers (GNAT) and Teachers and Education Workers Union (TEWU) (2010) revealed that a substantial number of teachers left the classroom 
annually especially in rural areas to search for better jobs elsewhere. The survey further suggested that about 10,000 teachers leave the classroom every year for other professions (Bame, 1991; GNAT, 2018; 2018; Cobbold, 2015; Acheampong \& Gyasi, 2019). The worst affected areas were the rural communities, where teachers naturally refused posting. As long recognised, whenever and wherever schools have high attrition of professional teachers for a long period, poor educational standards in terms of learners achievement and discipline, as well as administrative costs are disruptive to educational planning (Theobold, 1990; Konadu, 1994; Evans, 2018). High levels of teacher attrition may result in significant decreases in pupils' academic performances (Bempah et al., 1994; Alolo, 2016) and also may indicate underlying problems and disrupt the effectiveness of schools (Ingersoll \& Rossi, 2001; 2018). Although some degree of attrition is inevitable and perhaps desirable, high rates of teacher attrition can be costly to the reputation of an institution and instruction (Mereku, 2000).

\subsection{State policies to increase enrolment of pupils}

The Government of Ghana in partnership with donor agencies launched the following pro-poor policies: the Accelerated Development Plan for Education was introduced in 1951, free Compulsory Universal Basic Education (fCUBE) and in 2003 Ghana's Education Strategic Plan (ESP), a comprehensive medium-term strategy covering 2003-2015 and 2010-2020 was introduced to advance the fCUBE goals. The ESP situates the fCUBE within the Education for All goals to promote quality learning outcomes, equitable access and life-long learning (Nyarkoh et al., 2018; UNESCO, 2015; Nugba, 2020). Currently, Free Senior High School to make education more accessible to the Ghanaian child after successful completion of Junior High School. This policy has provided more schools with many children with inadequate teachers to teach in these schools especially in the rural areas because the number of qualified teachers graduating from the Colleges of education and the universities each year is enough but due to unequal teacher distribution, rural areas are the worst affected (Ministry of Education Report, 2010; 2017).

\subsection{State policies to increase teacher population}

The Government of Ghana has committed itself to provide enough teachers for all schools at all levels. This led to series of packages to entice people to enter the teaching profession and be trained as teachers. Over the years, these packages include:

Free teacher training program in the nation's teacher training colleges (now known as colleges of education), provision of a monthly stipend for teacher trainees, provision of study-leave with pay for teachers to pursue teacherrelated degree programs at the universities after serving for a minimum number of three years, provision of free teacher accommodation in relevant communities, provision of car maintenance allowances to teachers among others (Ghana National Education Campaign Coalition, 2013).

The above interventions are being provided to attract and retain teachers in the profession and reduce the teacher attrition rate.

As a temporary measure to curb the high teacher attrition rate in rural areas in Ghana, successive governments since 1965 to date, did engage the services of untrained teachers, Nation Builders Corps, and National Service Persons to work for a year or more because of inadequate qualified teachers in rural communities which invariably affected quality teaching and learning outcomes. One sad part of these young graduates from the Universities and Colleges of education to serve as National Service is that they were withdrawn from the rural areas to the cities because those in authority at the district level complained that they could not monitor their activities in the rural communities. With all these laudable interventions by successive governments, they lack the political will to enforce the law regulating postings and transfers of teachers from rural to urban areas and vice versa. In Ghana, all institutions are controlled by politicians and influential people in the community who have the power to instruct authorities to transfer and post teachers who are related to them to nearby areas thereby starving the rural areas.

\subsection{The current teacher population and distribution in Ghana}

In 2019, the public Ghanaian primary school teaching staff stood at 168,546. The public primary school level in Ghana has seen an increase in teacher population with a significant increase between 2017 and 2018 (Danso et al., 
2021). In the Kumasi Metropolitan area of Ghana, the total teacher population stood at 2,457 in January 2021. In view of these numbers, teachers are overstaffed in the urban areas in Ghana as against the rural communities. Though Ghana Government has trained more teachers, the major problem is about the equitable distribution of these teachers. As of 2018, the national teacher-pupil ratio was 1:29 (one teacher per 29 pupils).

Teacher distribution of teachers to rural communities is still problematic. Data from the District Education Office in Nsuta indicated a huge shortfall of trained teachers in rural communities in the district.

The main objective of the study was to assess the extent of teachers' distribution to Primary and Junior High Schools in rural areas in Sekyere Central District, Ashanti Region-Ghana.

\section{Research questions}

1. To what extent is the distribution of primary and junior high school teachers between schools equitable?

2. What are the reasons for the uneven distribution of primary and junior high school teachers between schools?

The contributions of the study are:

First, identifying relevant policies, strategies and instruments for addressing the major problems of teacher deployment and utilisation in Ghana.

Second, developing appropriate work tools and indicators for the diagnosis and monitoring of teacher deployment and utilisation in Ghana especially rural communities

Third, contributing to building up national capacities in the field of teachers' distribution through the development of context-related teaching materials.

Again, the study will contribute to theory development in the education management literature from a developing country perspective.

The recommendations would also inform School Management Committees and Parent-Teacher Associations in addressing many challenges impeding the development of the human resource in their rural communities.

\section{Empirical review}

Rural area, according to Johnson and Strange (2005), is the vicinity beyond metropolitan cities with a population of less than two thousand five hundred (2,500) people. Monk (2007) associates rural areas with economic activities which are agriculturally oriented. Again, populations less than 5000 are classified as rural areas. Based on this, 49\% of Ghana's population is rural and 170 out of the 254 districts/municipal/metropolitan administrative areas in Ghana are predominantly rural (Ghana Satistical Service, 2014). This study combines these definitions and consequently, defines rural schools as schools located in hard-to-reach areas with small and sparse population who are predominantly peasant farmers with inhabitants less than 5,000. The Ministry of Education (MoE) classifies districts, administrative areas in Ghana into deprived and non-deprived using indicators such as students retention, the pass rate in the national test and the share of trained teachers in the public Primary and Junior High Schools (ESPR, 2015; Budu, 2020). Rural settings in Ghana are mostly characterised by villages surrounded by other smaller settlements (cottages, hamlets and homesteads). They are connected to the main village by footpaths and sometimes feeder (red dirt) roads. Many children outside the main village walk several hours to school (Anlimachie, 2015; 2016; 2019).

Agriculture is the main economic activity of rural folks employing $75 \%$ of men and $58 \%$ of women workforce (FAO, 2012). Anlimachie (2016) found that pupils who commute long distances to school daily are associated with lower attendance, high dropout rate and poor educational outcomes in rural areas. Educational inequality in Ghana especially in rural areas is attributed to a low community or parents' participation. Parents/community members perceived teachers in rural areas as unqualified and hence, they do not treat them with respect or dignity (Anlimachie, et al., 2020; Essuman \& Acheampong, 2011; Edzii, 2017). Cobbold (2006) posits that the geographical disadvantage of some areas in Ghana makes it difficult to retain qualified teachers who will be able to share their rich experiences with pupils. Poor educational outcomes in rural areas also link to socio-cultural practices such as early marriage, religion and poverty (Fentiman et al., 1999; Malé, 2016). The obstacles to improve learning outcomes in Ghana include: low qualityadjusted learning years, poor accountability mechanisms, poor infrastructure and instructional resources, and ineffective 
utilisation of resources. Teachers assigned to teach in rural schools repeatedly refer to poor work conditions as a feature of disappointment and increased possibility to run off. These work conditions take account of poor facilities, the scarce number of course packs and supplies as well as large class sizes (NCTAF, 2002; World Bank, 2018). The World Bank (2010) notes down some countryside schools which do not have access to electricity. In addition, several rural teachers sigh the poor condition of their accommodation facilities and the long distance between their place of abode and schools. Furthermore, low remuneration, need for access to professional prospects, the responsibility to take on multiple duties and lack of public transportation in most rural areas have forced teachers to depend on personal automobiles and put up with the brunt of increased cost of living (Monk, 2007). Marwan et al. (2012) establish that some schools can merely be reached through restricted access roads or via rivers. Given that rural schools are characteristically small, teachers are required to carry teaching loads in multiple subjects. This demands greater preparation time for teachers and plausibly places greater strain on teachers having to cope with diverse subject content at the same time. Adding up to teaching numerous subjects, teachers are regularly forced to concurrently teach a broad array of pupils capacity (Monk, 2007), as well as various age groups at the same time (World Bank, 2010). It is noteworthy to keep in mind that rural teaching takes account of teaching indigent, neglected or emaciated pupils thus repeatedly likened to sporadic school attendance and greater student needs. This places an extra challenge for already overworked rural teachers to guarantee students teaching and learning (Monk, 2007).

Monk's study (2007), illustrates that rural teachers experience socio-cultural seclusion from relatives and acquaintances. Since countless of these rural areas are severely impoverished and allied with aging inhabitants, joblessness and low quality of life, scores of teachers chiefly those from the municipal environments are faced with difficulty when trying to hang out, which adds to their job frustration (NCTAF, 2002). Research has made known that rural teachers usually receive less access to teaching resources and teacher support programs owed to their geographic remoteness (Ingersoll, 2001). Every organization needs three main resources to survive. Even if an organization has got all the money and the materials it needs, it must still find capable people to put them into effective use. It is, therefore, safe to claim that human resources are essential resources of an organization. It is equally true to say that human resources are the highest asset of any organization, because no matter the amount of capital invested in an organization in terms of infrastructure and materials, its success or failure depends on the quality of people who plan and execute its programs, therefore, the development of the competencies, in terms of knowledge, skills, abilities and attitudes of people is cardinal to the development of society (DeSimone \& Werner, 2012).

The effect of the teachers on the performance of the students is germane. The teachers are the facilitators who are to impact the students the concepts expected to be learnt. However, Ramesh-Rao and Jani (2011) thought that the lack of teachers in basic schools grossly contributes to students' low performance. When considering growth in technology, the development of the human resources is paramount (Owusu-Acheampong, 2015). In consonance with Owolabi and Adedayo (2012) who noted that the problem of industrial development is attributable to the inadequacy of sufficiently trained human resources and this has been a major hurdle on technological and economic development of developing countries. The teacher is the fundamental pillar tasked with the responsibility of creating and sharing with pupils. The availability of professional teachers in rural primary and junior high schools is not encouraging (Krei, 2000). Teaching is seen as a dumping ground for any unemployed school leaver, irrespective of their area of specialisation. This group of young men and women thus handle the job as a bye-pass venture to their desired ends (Akinfe et al., 2012). Consequently, their contribution to the job would be very low since they lack the dedication demanded by the job (Owolabi \& Adedayo, 2012). The few ones that seem to show little dedication lack the technical know-how of teaching since they were never trained on the job. The resultant effect on the students' performance is disastrous. This eventually results in a decline in the development of human resources which adversely affects national development (Ramesh-Rao \& Jani, 2011). Sometimes, the schools are understaffed and parents are often worried about the safety of their children. Quite often, the parents' reluctance has a rational basis, and these gaps to need to be addressed. Many school heads explain that in their effort to cope with the teacher shortage, they employ "untrained" teachers: high school graduates who have completed a short induction to teaching course as part of a government initiative to support rural schools. These teachers are enthusiastic and hardworking but lack the essential knowledge and teaching skills that are needed to deliver a quality education (Strange, 2011). 


\section{Materials and methods}

The study uses conceptual, theoretical and empirical reviews to analyse concepts, and also identify the current gaps in knowledge on rural educational research. The defined variables for this paper are teachers and pupils in primary and junior high schools in the rural context. The topic is the realities of teacher distribution in primary and junior high schools in ghana: experiences of rural areas in Sekyere Central District. The research questions that guided the study were: to what extent is the distribution of primary and junior high school teachers between schools equitable and what are the reasons for the uneven distribution of primary and junior high school teachers between schools in rural areas in Sekyere Central District?

Secondary data from the Education Management Information System (EMIS) (2021) and document analysis were for this study. Data on teacher situations in the public Primary and Junior High schools in rural communities were extracted from the EMIS annual report 2021. The purposive and convenient sampling techniques were employed to select schools in the rural communities for the study. The data was organised to reflect the teacher population in each school from Primary (1-6) and Junior High (1-3) schools in the rural areas in Sekyere Central District in the Ashanti Region of Ghana. Aframso No. 2, Kyease, Kyekyebon, Balana, Birem, Koduase, Abotare Ye and Asougya were the communities the data on teachers and pupils were extracted from EMIS and other documents for the study.

\section{Results}

Objective 1: To determine the distribution of teachers in primary and Junior High Schools.

Evidence of Teacher Distribution for 2021/2022 Academic Year.

Table 1. Evidence of distribution of teachers to Junior High Schools

\begin{tabular}{cccccc}
\hline & Birem St. John JHS & Aframso D/A JHS & Asougya D/A JHS & Birem Pentecost JHS & Birem D/A JHS \\
\hline Male & 06 & 03 & 04 & 07 & 07 \\
Female & - & 04 & - & - & - \\
Total & 06 & 07 & 04 & 07 & 07 \\
\hline
\end{tabular}

From Table 1, the total teacher population stood at 31 with a shortfall of 14 teachers. The major problem at the junior high level teaching is that teachers specialised in one subject area, if a teacher who is trained to teach mathematics is lacking in the school, then it means that the students cannot learn mathematics. This inavariably will affect students' learning outcomes.

Total teacher population in the junior high schools 31 .

Teachers deficit nine (14).

Table 2. Evidence of students population in Junior High Schools for 2021/2022

\begin{tabular}{cccccc}
\hline & Birem St. John JHS & Aframso D/A JHS & Asougya D/A JHS & Birem Pentecost JHS & Birem D/A JHS \\
\hline Boy & 87 & 125 & 99 & 98 & 108 \\
Girl & 89 & 98 & 97 & 89 & 97 \\
Total & 176 & 223 & 196 & 187 & 205 \\
\hline
\end{tabular}


Total enrolment in the Junior High Schools $=987$.

Teacher-pupil ratio $(\mathrm{TPR})=987 / 31=31.8(1: 31)$.

Note: the subjects at the junior high school are 8 (English Language, Mathematics, Integrated Science, Religious and Moral Education, Ghanaian Language, Creative Arts, Information Communication Technology, French, PrevoTech). These subjects require teachers have the requisite knowledge in one of them to be able to teach well, but evidence from Table 2, suggests that each school, lack one or two teachers to teach a particular subject. In the five junior high schools, nine teachers' deficits were recorded which is a huge gap created as a result of some of the teachers' unwillingness to teach in rural areas. The core mandate of the headteachers/mistresses is to provide a supervisory role in the school. Ideally, headteachers are not supposed to teach but in the rural areas, they are compelled to teach and supervise instruction because of inadequate teachers in their respective schools. Again, headteachers may teach in case a class teacher travels or is indisposed.

Table 3. Evidence of teacher distribution in Primary Schools

\begin{tabular}{|c|c|c|c|c|c|c|c|c|c|c|}
\hline & $\begin{array}{c}\text { Aframso } \\
\text { Prim No. } 2\end{array}$ & $\begin{array}{l}\text { Kyease D/ } \\
\text { A Prim }\end{array}$ & $\begin{array}{c}\text { Kyekyebon } \\
\text { D/A } \\
\text { Primary }\end{array}$ & $\begin{array}{c}\text { Birem } \\
\text { Pentecost } \\
\text { Prim }\end{array}$ & $\begin{array}{c}\text { Balana D/ } \\
\text { A Prim }\end{array}$ & $\begin{array}{c}\text { Birem D/A } \\
\text { Prim }\end{array}$ & $\begin{array}{l}\text { Koduase } \\
\text { D/A Prim }\end{array}$ & $\begin{array}{l}\text { Birem } \\
\text { Roman } \\
\text { Prim }\end{array}$ & $\begin{array}{c}\text { Birem D/A } \\
\text { Prim }\end{array}$ & $\begin{array}{c}\text { Abotare Ye } \\
\text { Prim }\end{array}$ \\
\hline $\begin{array}{c}\mathrm{M} \\
\text { (Male) }\end{array}$ & 4 & 3 & 3 & 5 & 4 & 1 & 3 & 3 & 5 & 4 \\
\hline $\begin{array}{c}\mathrm{F} \\
\text { (Female) }\end{array}$ & - & - & - & - & - & - & - & - & - & - \\
\hline Total & 4 & 3 & 3 & 5 & 4 & 1 & 3 & 3 & 5 & 4 \\
\hline
\end{tabular}

EMIS, 2021

From Table 3, the teacher population was 35 with a deficit of 35 teachers.

All ten (10) primary schools were understaffed with a teacher deficit of 35 which is so huge. Primary education is the foundation builder of all learners one would have thought that much attention is paid to rural education as compared to those in the urban areas.

Table 4. Population distribution of pupils for the 2021/2022 Academic Year

\begin{tabular}{|c|c|c|c|c|c|c|c|c|c|c|}
\hline & $\begin{array}{c}\text { Aframso } \\
\text { Prim No. } 2\end{array}$ & $\begin{array}{l}\text { Kyease D/ } \\
\text { A Prim }\end{array}$ & $\begin{array}{c}\text { Kyekyebon } \\
\text { D/A } \\
\text { Primary }\end{array}$ & $\begin{array}{c}\text { Birem } \\
\text { Pentecost } \\
\text { Prim }\end{array}$ & $\begin{array}{l}\text { Balana D/ } \\
\text { A Prim }\end{array}$ & $\begin{array}{l}\text { Birem D/A } \\
\text { Prim }\end{array}$ & $\begin{array}{l}\text { Koduase } \\
\text { D/A Prim }\end{array}$ & $\begin{array}{c}\text { Birem } \\
\text { Roman } \\
\text { Prim }\end{array}$ & $\begin{array}{l}\text { Birem D/A } \\
\text { Prim }\end{array}$ & $\begin{array}{c}\text { Abotare Ye } \\
\text { Prim }\end{array}$ \\
\hline $\begin{array}{c}\text { B } \\
\text { (Boy) }\end{array}$ & 183 & 132 & 173 & 173 & 62 & 226 & 183 & 120 & 224 & 75 \\
\hline $\begin{array}{c}\mathrm{G} \\
(\mathrm{Girl})\end{array}$ & 169 & 140 & 165 & 165 & 68 & 175 & 138 & 190 & 170 & 66 \\
\hline Total & 352 & 272 & 338 & 338 & 130 & 401 & 321 & 310 & 394 & 141 \\
\hline
\end{tabular}

EMIS, 2021

From Table 4, the total enrolment was 3,050 pupils. The total number of teachers was 35 with a shortfall of 35 teachers. Therefore, the teacher-pupil ratio $(\mathrm{TPR})=3050 / 35=87$. Teacher-pupil ratio in the primary schools stood at $1: 87$. This means that one teacher is controlling 87 pupils in each class which is much higher as compared to the national teacher-pupil ratio of 1: 29 .

Teacher-pupil ratio $(\mathrm{TPR})=3050 / 35=87$. 
The teacher-pupil ratio in the primary schools stood at 1:87.

From the Tables, it is evident that teachers in rural communities are woefully inadequate to meet the demand for rural education. From the Tables, there is a lot of teachers' deficit in all schools and all class levels. In the Primary schools, the teacher population stood at 35 while total enrolment was 3,050. In terms of teacher-pupil ratio (1:87), one teacher per 87 pupils is on the higher side as compared to the national teacher-pupil ratio of 1:27 in 2019. Again, in the Junior High Schools, the total teacher population was 31 while total enrolment was 987 (TPR = 987/31=32 (1:32)).

The total enrolment in the rural communities stood at (primary, 3,050 + JHS, $987=4,037$ ). Total teacher population (Primary, $35+$ JHS, $31=66$ ). Therefore, the teacher-pupil ratio is $4,037 / 66=61(1: 61)$. It is evident that the teacherpupil ratio (1:61) is higher in the rural communities as compared to the National teacher-pupil ratio of 1:29.

In terms of gender representation, female teachers were highly disproportionate.

Again, the teachers in Ghana at the primary school level teach all subjects. Ideally, one teacher is assigned to each class (primary 1 to primary 6).

\section{Discussion}

\subsection{Reasons for the uneven distribution of teachers in rural areas in Ghana}

Quality education is highly relative and it is meant differently in different jurisdictions. In Ghana, all learners do not enjoy the same quality of teaching and learning as highly qualified teachers are overstaffed in urban centers more than in rural areas. The sad issue of concern is the fact that these learners study the same curriculum, and write the same examination with their counterparts in the urban areas. Teachers in urban areas receive the same salary as those teaching in rural communities. The current educational reforms critically looked at inclusivity, gender which were the main pillar in the new curriculum in all levels of education. The worrying trend is that female teachers were underrepresented in rural communities. The failure of authorities to encourage and motivate female teachers to accept posting to rural areas is still problematic. Female teachers will serve as role models to the rural girls so they can emulate them and invariably become useful to the community and the nation as a whole. The realisation of quality education for all cannot be achieved since there are greater disparities in the provision of education to the Ghanaian child. In the context of manpower utilisation, teachers in urban areas who are overstaffed do less work than those in rural areas. Ninety percent of workers in the school system are teachers. One of the key variables determining the supply and demand for teachers in Primary and Junior High schools is the utilisation of teachers. Teacher utilisation is determined by the assignment of workload which is teaching hours per week for each teacher. Another determinant is the class size, teacher-pupil ratio. The third variable is the management of teachers. This relates to the supervisory role of headteachers and other supervisors (World Bank Global Education Centre, 2015).

The long-term solution to the problem rests in increasing the supply of qualified teachers to rural communities. If the supply exceeds the demand, the schools in all the regions can recruit teachers from the market and dependence on central deployment will cease to function. The fact that the problem is recognised and policy guideline is set, it is a major step forward. However, with the current high learner-teacher ratio, ever-increasing enrolment, high transition to the Senior High Schools and expansion of the system in general satisfying the need for qualified teachers cannot be a reality of the very near future. Until then, some mechanisms of fairly distributing the available qualified teachers should be sought.

\subsection{Policy implications}

\subsubsection{Consider different salary scale for rural and urban teachers}

The salary of teachers in Ghana, in general, is not uniform with other colleagues with similar qualifications in other organisations. Besides, the basic salary is the same irrespective of the place a teacher is assigned to teach. Reconsidering the national salary scale of teachers and substituting it with a given minimal range would give the less desired districts some degree of freedom to use salary as a positive balance to attract teachers to stay and work in rural communities. Review of the 20 percent top-up allowance for teachers in deprived areas to motivate trained teachers to rural areas. 


\subsubsection{Transfer policies}

Transferring teachers from one location to another has its own challenges. On the one hand, it will leave the remote regions with fresh and inexperienced teachers. On the other hand, urban areas have already been overstaffed with experienced teachers. A solution that could strike a balance between these two problems should be considered. The best approach seems to develop a scheme where a given percentage of salary increase be given to teachers who teach in remote places.

\subsubsection{Special packages for teachers in rural communities}

Teachers working in remote areas face a number of challenges. Among other things, these include poor road network, lack of electricity, inadequate clean water, lack of good hospitals and even indecent housing. In order to make the remote areas more attractive to teachers, special incentives should be made available for teachers deployed in these areas. These might include the provision of extra allowances, free medical care for those teaching in remote areas, premium health insurance, free accommodation and interest-free loans to teachers in remote areas. It is clear that substantial financial resources will be required to realise these suggestions. It is also understandable that in Ghana such investments pose difficult problems in the current financial and economic climate. The scarcity of resources in the face of large needs will not grant the education sector all that it needs. Yet, the nation has to prioritise and commit itself in terms of allocation of scarce resources if educational goals set are to be achieved. Teacher recruitment programs, will not solve the staffing problems of schools if they do not address the issue of low teacher retention. Consequently, besides the development of recruitment-oriented policies, retention should be the target of ambitious educational policies for all Governments in Ghana.

Lastly, authorities in charge of postings, transfers, promotions and demotions should be allowed to independently carry out their duties without any political interference. This will go a long way to ensure that all schools are properly and evenly staffed with the qualified teachers.

\section{References}

Acheampong, P., \& Gyasi, J. F. (2019). Teacher retention: A review of policies for motivating rural basic school teachers in Ghana. Asian Journal of Education and Training, 5(1), 86-92.

Akinfe, E., Olofinniyi, O. E., \& Fashiku, C. O. (2012). Teachers' quality as correlates of students academic performance in biology in senior secondary schools of Ondo State, Nigeria. Journal of Education Research, 1(6), 108-114.

Alolo, S. (2016). Bush allowance: A phenomenological study on sexual exploitation of schoolgirls by male teachers in rural schools in Northern Ghana. Doctoral dissertation, Creighton University.

Anlimachie, M. A. (2015). Towards equity in access and quality in basic education in Ghana: Comparative strategies for the rural and urban milieu. American Journal of Social Issues and Humanities, 5(2), 400-426.

Anlimachie, M. A. (2015). Viewing the influences of "the global" on education in Ghana from the Lens of Human Rights Approach. International Journal of Humanities and Social Sciences, p-ISSN, 1694-2620.

Anlimachie, M. A. (2016). Achieving Equity in Basic Education in Ghana; Contexts and Strategies. Master's thesis.

Anlimachie, M. A. (2019). Enacting eelevant basic education to bridge the rural-urban inequality in Ghana; The prospects and approaches for investigating rural educational realities. International Journal of Humanities and Social Sciences, 11(1), 42-58.

Anlimachie, M. A., \& Avoada, C. (2020). Socio-economic impact of closing the rural-urban gap in pre-tertiary education in Ghana: context and strategies. International Journal of Educational Development, 77, 102236.

Ansong, D., Renwick, C. B., Okumu, M., Ansong, E., \& Wabwire, C. J. (2018). Gendered geographical inequalities in junior high school enrollment. Journal of Economic Studies, 45(2), 0144-3585.

Asim, S., Chimombo, J., Chugunov, D., \& Gera, R. (2017). Moving teachers to Malawi's remote communities: A datadriven approach to teacher deployment. Education Global Practice Group, World Bank Group.

Bame, K. N. (1991). Teacher Motivation and Retention in Ghana. Accra: Ghana University Press.

Bempah, E. O., Kaylen, M. S., Osburn, D. D., \& Birkenholz, R. J. (1994). An econometric analysis of teacher mobility. Economics of education review, 13(1), 69-77.

Bird, L., Moon, B., \& Storey, A. (2013). The context for teacher education in developing countries. In B. Moon (Ed.), 
Teacher education and the challenge of development: A global analysis (pp. 19-21). Routledge.

Buckler, A. (2015). Quality teaching and the capability approach: Evaluating the work a governance of women teachers in rural sub-Saharan Africa. Routledge.

Budu, E. (2020). Predictors of home births among rural women in Ghana: analysis of data from the 2014 Ghana Demographic and Health Survey. BMC Pregnancy and Childbirth, 20(1), 1-8.

Cobbold, C. (2015). Solving the teacher shortage problem in Ghana: Critical perspectives for understanding the issues. Journal of Education and Practice, 6(9), 71-79.

Crawfurd, L. \& Pugatch, T. (2020). Teacher labor markets in developing countries. IZA DP No. 12985. Institute of Labor Economics, Bonn.

Danso, L. A., Adjei, J. K., \& Yaokumah, W. (2021). EMIS Success Modeling Using Information Systems Quality Factors. International Journal of Information Systems in the Service Sector (IJISSS), 13(3), 65-81.

DeSimone, R. L., \& Werner, J. M. (2012). Human Resource Development (6th ed.). SouthWestern Cengage Learning, Canada.

Dladla, N., \& Moon, B. (2013). Teachers and the development agenda: An introduction. In B. Moon (Ed.), Teacher education and the challenge of development: A global analysis (pp. 5-17). Routledge.

Edzii, A. (2017). Decentralised educational planning: a case study of two districts in Ghana. PhD Thesis, University of Sussex.

ESPR. (2015). Education Sector Performance Report. Ministry of Education, Accra. Ghana.

Essuman, A., \& Akyeampong, K. (2011). Decentralisation policy and practice in Ghana: the promise and reality of community participation in education in rural communities. Journal of Education Policy, 26(4), 513-527.

Evans, D. K., \& Yuan, F. (2018). The working conditions of teachers in low-and middle-income countries. World Bank 2018 World Report.

FAO. (2012). Gender inequalities in rural employment in Ghana. An overview. Food and Agricultural Organization. http://www.fao.org/3/ap090e/ap090e00.pdf

Fentiman, A., Hall, A., \& Bundy, D. (1999). School enrolment patterns in rural Ghana: A comparative study of the impact of location, gender, age and health on children's access to basic schooling. Comparative Education, 35(3), pp. 331-349.

Ghana National Education Campaign Coalition. (2013). Teacher Gaps in Public Basic Schools in Ghana. Global Action Week.

Ghana Statistical Service. (2014). Ghana Living Standard Survey Round 7. Accra, Ghana: Ghana Statistical Service (GSS).

GNAT. (2018). Teacher Attrition in Ghana. https://www.graphic.com.gh/news/education/high-annual-attrition-rate-ofteachers-worrying-gnat.html

Ingersoll, R. M. (2001). Teacher turnover, teacher shortages, and the organization of schools (Document R-011). Seattle, WA: Centre for the Study of Teaching and Policy, University of Washington. https://repository.upenn.edu/ cgi/viewcontent.cgi?article $=1069 \&$ context $=$ cpre_researchreports

Ingersoll, R., Merrill, L., Stuckey, D., \& Collins, G. (2018). Seven trends: The transformation of the teaching forceupdated October 2018. CPRE Research Reports. University of Pennsylvania, Scholarly Commons.

Johnson, J., \& Strange, M. (2005). Why rural matters? The facts about rural education in the 50 states. Arlington, VA.: Rural School and Community Trust.

Konadu, D. A. (1994). Improving the deployment of teachers: The Ghanaian experience. UNESCO, International institute for educational planning.

Krei, M. S. (2000). Teacher transfer policy and the implications for equity in urban school districts. American Educational Researchers Association, New Orleans.

Lumor, E. K. (2016). Factors affecting attrition and retention of public basic school teachers in the South Dayi District of Ghana. Doctoral dissertation, University of Education, Winneba.

Marwan, A., Sumintono, B., \& Mislan, N. (2012). Revitalizing rural schools: a challenge for Malaysia. Educational Issues, Research and Policies. UTM Press RMC.

Mereku, D. K. (2000). Demand and supply of basic school teachers in Ghana. National Teacher Education Forum. UCEW, Winneba.

Ministry of Education. (2010). Appraise all of the government of Ghana education sector plan, 2010-2020. Accra: Ghana Ministry of Education.

Ministry of Education. (2017). Report of the Education Reforms Review Committee on Pre-Tertiary Education. Accra.

Ministry of Education. (2010). Education Sector Medium Term Development Plan, 2010-2013. Accra: Ghana Ministry of Education. 
Monk, D. H. (2007). Recruiting and retaining high quality teaching in rural areas. The Future of Children, 17(1):155174.

Nugba, R. M. (2020). Evaluation of the effectiveness of junior high school education in the Central Region of Ghana. Doctoral dissertation, University of Cape Coast.

Nyarkoh, E., \& Intsiful, E. (2018). An assessment of the impact of international aid on basic education in Ghana. American Journal of Educational Research, 6(1), 43-49.

Owolabi, O. T., \& Adedayo, J. O. (2012). Effect of teacher's qualification on the performance of senior secondary school physics students: Implication on technology in Nigeria. English Language Teaching, 5(6), $1916-4742$. http://dx.doi.org/10.5539/elt.v5n6p72

Owusu-Acheampong, E. (2015). Examining the relationship between employees/apprentices human capital on their performance in small scale businesses in the sekondi-takoradi metropolis. International Journal of Small Business and Entrepreneurship Research. 3(1), 1-9.

Ramesh-Rao, R., \& Jani, R. (2011). Teacher allocation and equity in malaysian schools. International Journal of Institutions and Economies, 3(1), 103-112.

Strange, M. (2011). Finding fairness for rural students. Phi Delta Kappan, 92(6), 8-15.

Theobald, N. D. (1990). An examination of the influence of personal, professional, and school district characteristics on public school teacher retention. Economics of Education Review, 9(3), 241-250.

UIS. (2016). The world needs almost 69 million mew teachers to reach the 2030 education goals. UNESCO.

UNESCO, U. (2015). Education 2030: Incheon Declaration and Framework for Action Towards Inclusive and Equitable Quality Education and Lifelong Learning for All. UNESCO Institute for Information Technologies in Education. https://iite.unesco.org/publications/education-2030-incheon-declaration-framework-action-towardsinclusive-equitable-quality-education-lifelong-learning/

Wilson, S. D. (2018). Implementing co-creation and multiple intelligence practices to transform the classroom experience. Contemporary Issues in Education Research, 11(4), 127-132.

Witoszek, N. (2018). Teaching sustainability in Norway, China and Ghana: challenges to the UN programme. Environmental Education Research, 24(6), 831-844.

World Bank Group. (2016). Teacher management: Improving teacher deployment in Malawi. Education Global Practice: Innovations in Education Africa. World Bank. 